Original Article

\title{
Molecular Epidemiology of Plasmodium species in Conflicted Federally Administered Tribal Area (FATA) Pakistan
}

\author{
Epidemiologia molecular de espécies de plasmódio em área tribal sob administração \\ federal em conflito do Paquistão
}

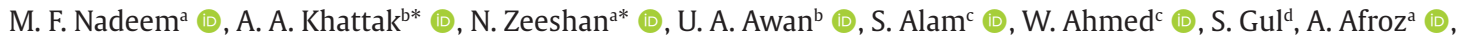 \\ K. Sughraa (D), U. Rashid a and M. A. U. Khan ${ }^{a}$ \\ aUniversity of Gujrat, Department of Biochemistry \& Biotechnology, Gujrat, Punjab, Pakistan \\ ${ }^{\text {b} T h e ~ U n i v e r s i t y ~ o f ~ H a r i p u r, ~ D e p a r t m e n t ~ o f ~ M e d i c a l ~ L a b o r a t o r y ~ T e c h n o l o g y, ~ H a r i p u r, ~ K h y b e r ~ P a k h t u n k h w a, ~ P a k i s t a n ~}$ \\ 'The University of Haripur, Department of Microbiology, Haripur, Khyber Pakhtunkhwa, Pakistan \\ dNational University of Medical Sciences, Department of Biological Sciences, Rawalpindi, Punjab, Pakistan
}

\begin{abstract}
Military conflicts have been significant obstacles in detecting and treating infectious disease diseases due to the diminished public health infrastructure, resulting in malaria endemicity. A variety of violent and destructive incidents were experienced by FATA (Federally Administered Tribal Areas). It was a struggle to pursue an epidemiological analysis due to continuing conflict and Talibanization. Clinical isolates were collected from Bajaur, Mohmand, Khyber, Orakzai agencies from May 2017 to May 2018. For Giemsa staining, full blood EDTA blood samples have been collected from symptomatic participants. Malaria-positive microscopy isolates were spotted on filter papers for future Plasmodial molecular detection by nested polymerase chain reaction (nPCR) of small subunit ribosomal ribonucleic acid (ssrRNA) genes specific primers. Since reconfirming the nPCR, a malariometric study of 762 patients found 679 positive malaria cases. Plasmodium vivax was 523 (77\%), Plasmodium falciparum $121(18 \%), 35$ (5\%) were with mixed-species infection ( $P$. vivax plus $P$. falciparum), and 83 were declared negative by PCR. Among the five agencies of FATA, Khyber agency has the highest malaria incidence (19\%) with followed by P. vivax (19\%) and P. falciparum (4.1\%). In contrast, Kurram has about (14\%), including (10.8\%) P. vivax and (2.7\%) $P$. falciparum cases, the lowest malaria epidemiology. Surprisingly, no significant differences in the distribution of mixed-species infection among all five agencies. P. falciparum and P. vivax were two prevalent FATA malaria species in Pakistan's war-torn area. To overcome this rising incidence of malaria, this study recommends that initiating malaria awareness campaigns in school should be supported by public health agencies and malariarelated education locally, targeting children and parents alike.
\end{abstract}

Keywords: FATA, Malaria, Pakistan, Molecular Epidemiology, Plasmodium, falciparum, vivax.

\begin{abstract}
Resumo
Os conflitos militares têm sido obstáculos significativos na detecção e tratamento de doenças infecciosas devido à diminuição da infraestrutura de saúde pública, resultando na endemicidade da malária. Uma variedade de incidentes violentos e destrutivos foi vivida pelas FATA (áreas tribais administradas pelo governo federal). Foi uma luta buscar uma análise epidemiológica devido ao conflito contínuo e à talibanização. Isolados clínicos foram coletados de agências Bajaur, Mohmand, Khyber e Orakzai, de maio de 2017 a maio de 2018. Para a coloração de Giemsa, amostras de sangue completo com EDTA foram coletadas de participantes sintomáticos. Isolados de microscopia positivos para malária foram colocados em papéis de filtro para futura detecção molecular plasmódica por reação em cadeia da polimerase aninhada (nPCR) de primers específicos de genes de subunidade ribossômica de ácido ribonucleico (ssrRNA). Desde a reconfirmação do nPCR, um estudo malariométrico de 762 pacientes encontrou 679 casos positivos de malária. Plasmodium vivax foi 523 (77\%), Plasmodium falciparum 121 (18\%), 35 (5\%) eram com infecção de espécies mistas ( $P$. vivax mais $P$. falciparum) e 83 foram declarados negativos por PCR. Entre as cinco agências da FATA, a agência Khyber tem a maior incidência de malária (19\%), seguida por $P$. vivax (19\%) e $P$. falciparum (4,1\%). Em contraste, Kurram tem cerca de $14 \%$, incluindo $10,8 \%$ casos de $P$. vivax e 2,7\% P. falciparum, a epidemiologia de malária mais baixa. Surpreendentemente, não há diferenças significativas na distribuição da infecção de espécies mistas entre todas as cinco agências. P. falciparum e $P$. vivax foram duas espécies prevalentes de malária FATA na área devastada pela guerra no Paquistão. Para superar essa incidência crescente de malária, este estudo recomenda que o início de campanhas de conscientização sobre a malária na escola deve ser apoiado por agências de saúde pública e educação relacionada com a malária localmente, visando crianças e pais.
\end{abstract}

Palavras-chave: FATA, Malária, Paquistão, Epidemiologia Molecular, Plasmodium, falciparum, vivax.

*e-mail: amir.khattak@hotmail.com; nadia.zeeshan@uog.edu.pk

Received: January 4, 2021 - Accepted: March 29, 2021 


\section{Introduction}

Malaria is the world's most common arthropodborne disease transmitted by the protozoa of the genus Plasmodium responsible for the death of about 0.43 million deaths annually. About 228 million malaria cases, including 208 million at-risk persons, were reported globally in 2019, with around 0.7 million only from Pakistan. According to the World Health Organization (WHO), it is startling that Pakistan is one of the seven top countries in the Eastern Mediterranean, with $P$. vivax and $P$. falciparum as the prevalent species comprising $98 \%$ of malaria prevalence. Moreover, the prevalence of Plasmodium species in this area varies from 75 to $85 \%$ P. vivax, 15 to $25 \%$ P. falciparum, and about $1 \%$ of both species' mixed infections (Khan et al., 2020; Qureshi et al., 2020b; Khattak et al., 2013a).

Pakistan's Federally Administered Tribal Region (FATA) was second on Pakistan's malaria-metric scale, where biological, where ecological, environmental and human intervention primarily affects outbreaks of infectious diseases. Militancy and political instability in FATA had devastating effects on the health systems of the region. Across the border, Afghan refugee movements and internal migration of people from war-affected agencies to neighboring areas, stuck in a vast number of temporary settlements and camps with rudimentary overcrowded dwellings; thus, increasing susceptibility to numerous infectious and vector-borne diseases (Karim et al., 2016).

Malaria was virtually eliminated from Afghanistan borders by the end of the 1970s due to malaria prevention programs (Gayer et al., 2007). However, by the end of the military operations in FATA, an upsurge of malaria was reported. According to a study, P. falciparum, which is already prevalent in Afghan refugees, and due to the massive influx of these migrants, a spike in the prevalence of $P$. falciparum was observed in Pakistan (Murtaza et al., 2004; Sheikh et al., 2005). Few studies documented low immunity for refugees, rendering them more vulnerable to malaria (Bouma et al., 1996; Khattak et al., 2013a). These factors may contribute to increased disease and transmission of malaria in refugees. In addition to the lack of critical long-term needs, discontinued disease surveillance, lack of healthcare services, and public awareness lead to more extreme consequences linked to the outbreak of infectious diseases (Morse, 2004; Soares-Pinheiro et al., 2017; Santos et al., 2004).

Plasmodium falciparum and Plasmodium vivax are the leading cause of malaria in Pakistan with $88 \%$ and $12 \%$, respectively (Qureshi et al., 2020a). The peak malaria prevalence recorded was $37 \%$ in the FATA region along with Pak-Afghan and the Iranian border. According to the National Malaria Control Program's report, FATA stood third in sharing its malaria burden after Sindh and Khyber Pakhtunkhwa (KP) provinces. Nevertheless, annual parasite incidence, blood examination rate, and test positivity rate were highest in FATA among all provinces and territories (Pakistan, 2019). In 2018, this preventable disease showed an upswing in cases due to the failure to introduce a successful antimalarial awareness campaign, especially in FATA and Balochistan.

FATA covering about $27,220 \mathrm{~km}$ with approximately 4.45 million population, has a weak public health system and infrastructure due to political instability, militancy, and unrest situation for more than a decade (Nawaz and de Borchgrave, 2009). Dreadfully, no molecular epidemiological experiments have been performed to assess malaria's actual status in the local population. This study provides the molecular epidemiology baseline parasitological information of malaria incidence and species distribution among different age groups and gender in five agencies of FATA, Pakistan.

\section{Materials and Methods}

FATA has a unique historical, political, and traditional status since British times, and this system was inherited by Pakistan and is still working almost similarly with a population of about 4.5 million. A semi-autonomous tribal region in north western Pakistan since 1947 until being merged with KP province in the year 2018. FATA has seven tribal agencies, now said as Tribal Districts (Khyber, Kurram, Orakzai, Mohmand, Bajaur, North, and South Waziristan), and Frontier Region (FR). Due to militancy, migration of internally displaced people/immigrants, and military operations, this area has been deprived of health care facilities and destroyed health infrastructure.

Monsoon season is peak malaria transmission season is during (July to August) this time varies based on their parasite species. P. falciparum has a single peak that comes after the summer season. In contrast, $P$. vivax has two peaks in a year in subtropical climates, which results in a malaria relapse attack (Rowland et al., 1997). P. vivax reaches its peak during the summertime, i.e., from June to September, whereas $P$. falciparum is responsible for the disease during late summer and winter, i.e., from August to December. In $P$. vivax, there is relapse peak seen due to transmission in the preceding year in the early summer (April to June). The predominant vectors include Anopheles culicifacies and Anopheles stephensi, while two new species have been reported in Balochistan, namely Anopheles fluviatilis and Anopheles annularis (WHO, 2019).

\subsection{Blood sampling}

Sampling for this project was collected from Basic Health Units and private health facilities of five districts (Bajaur, Mohmand, Khyber, Orakzai, and Kurram Agency) of FATA, KP, as shown in Figure 1. Clinical isolates and brief demographic history were collected from symptomatic malaria patients irrespective of age or sex and showed a willingness to participate in this study. Patients with malaria symptoms and those who did not sign the consent form were not enrolled in the study. A total of 3550 symptomatic malaria patients who visited public and private health care facilities between May 2017 to May 2018 were enrolled in this study. Trained phlebotomists drew $3 \mathrm{~mL}$ of intravenous blood from each patient at public and private healthcare 


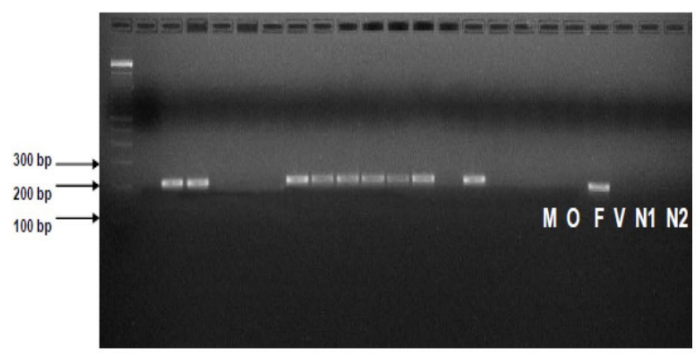

(a)

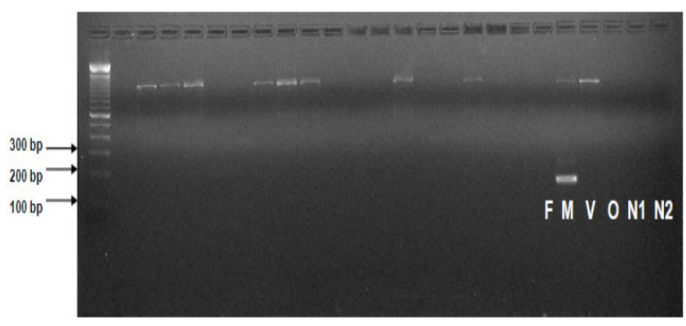

\section{(b)}

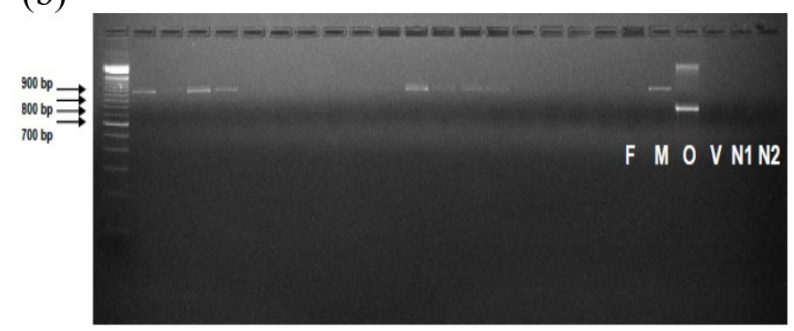

(d)

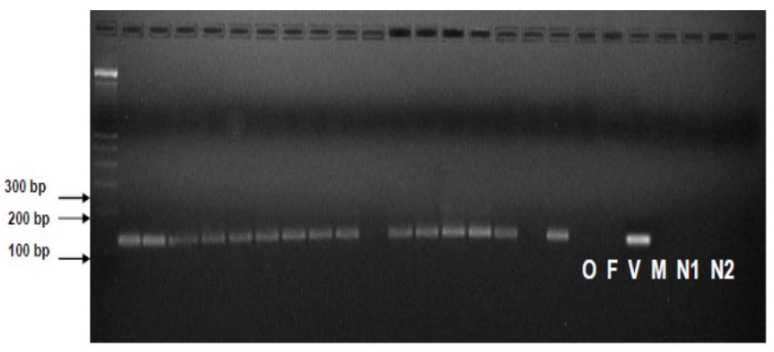

\section{(c)}

Figure 1. (a) Product of the second round of nested PCR showing Plasmodium falciparum bands (205 bp) on agarose gel against 100 bp DNA ladder (lane no 1). M: P. malariae, O: P. ovale, F: P. falciparum, V: P. vivax, N1-2: Negative Control; (b) Plasmodium vivax bands (120 bp) on agarose gel against 100 bp DNA ladder (Lane no 1); (c) Plasmodium malariae band (144 bp) on agarose gel against 100 bp DNA ladder (lane no 1); (d) Plasmodium ovale band (800 bp) on agarose gel against 100 bp DNA ladder (lane no 1).

centers. Ethical approval for this study has been taken from the Institutional Review Board of the University of Gujrat.

\subsection{Microscopy and blood spotting}

Thick and thin blood films of patients suspected of malaria were observed at x1000 after staining with $10 \%$ Giemsa solution by a trained technologist. Microscopy-positive 762 malaria samples were collected and stored at $-20^{\circ} \mathrm{C}$ before spotting them on filter paper. Samples were thawed, and approximately $50 \mathrm{uL}$ was applied to 3MM Whatman chromatography filter papers. Individual plastic bags were used to store air-dried filter papers with desiccant. DNA extraction was done from dried blood spot filter papers by the Qiagen DNA extraction kit.

\subsection{DNA extraction from dried blood spot protocol}

DNA was extracted from dried blood filter paper and was cut by a clean scissor. DNA was done from filter paper using QIAmp DNA extraction Blood Mini Kit (Qiagen, Germany) using the manufacturer-provided protocol.

\subsection{Plasmodium species identification PCR protocol}

The protocol was followed with few modifications to amply the malarial parasite DNA already described (Snounou et al., 1993; Singh et al., 1999). There were two rounds of nested PCR, first for genus Plasmodium and second for four species (P. falciparum, P. vivax, P. malariae, and $P$. ovale). Medicines for Malaria Venture (MMV) specie specific positive controls MRA-178 (P. vivax), 3D7 (P. falciparum), MRA-179 (P. malariae), and MRA-180 (P. ovale) were used. Ultra-pure water was used as a negative control with each batch of samples. In primary PCR, genus-specific oligonucleotides primer pair, fPLU and rPLU were used to amplify the conserved region of DNA sequences found in all four species. Amplified primary PCR product was used as the template for the second round of nPCR ( $P$. falciparum rFAL \& fFAL, P. vivax rVIV \& fVIV, P.malariae rMAL \& fMAL, and P. ovale rOVA \& fOVA primers pair). Both primary and secondary nested PCR assays were performed using Bio-Rad Thermal Cyclers (Bio-Rad). The nPCR product was stored at $-20{ }^{\circ} \mathrm{C}$ after completion of the second round of nPCR. Amplified nested PCR product was run at $200 \mathrm{~V}$ for 1 hour and 20 minutes on $2 \%$ agarose gel electrophoresis, along with a molecular ladder. This was followed by staining with $10 \%$ ethidium bromide, and the image was taken using the Bio-Rad gel doc system. All Plasmodium species showed their amplified DNA fragments at specific size P. falciparum (205 bp), P. vivax (120 bp), P. ovale (800 bp), and P. malaria (144 bp), as shown in Figure 1.

\section{Results}

\subsection{Prevalence of malarial infection in FATA}

A total of 762 (21\%) microscopy positive specimens were collected from five agencies of the FATA region from May 2017 to May 2018. Out of these, P. vivax parasite was identified in $623(82 \%)$ of the patients, while $P$. falciparum was found in 132 (17\%) subjects, 7 (1\%) patients were confirmed to have a mixed infection, as their blood smear revealed both $P$. falciparum and P. vivax (Table 1). On exposure to nPCR, only 679 (19\%) of 
the microscopy-positive samples tested positive, while 83 were found negative by PCR. PCR-confirmed cases were 523 out of 623 (77\%) for P. vivax and 121 out of 132 (18\%) for $P$. falciparum. Interestingly 35 (5\%) cases were found to be harboring mixed infection on molecular analysis, compared to only 7 (1\%) cases detected by microscopy.

Khyber has the highest prevalence of malaria (19\%), with the highest incidence of $P$. vivax (19\%) and $P$. falciparum (4\%) among five agencies of FATA. Kurram Agency with approximately (14\%) of lowest malaria epidemiology, including (10.8\%) of P. vivax and (2.7\%) of P. falciparum, as shown in Figure 2 . There were no significant variations in the distribution of mixed species infection among all five agencies. In the FATA region, two prevalent malarial species were Plasmodium falciparum and Plasmodium vivax, as shown in Figure 3.

\subsection{Gender and age wise prevalence of malaria positive cases}

Among patients who tested positive for Plasmodium DNA by PCR, 468 (69\%) were male, and 211 (31\%) were female. Patients were distributed between two age groups less than and greater or equal to 25 years. Patients with an age group less than 25 years showed peak malaria prevalence (61\%), as shown in Table 2.

\subsection{Discrepancies in district-wise PCR positive malaria cases}

A district-wise result of PCR confirmed samples is shown in Table 3. The ratio of $P$. falciparum and $P$. vivax infection was between 1:4 and 1:5 among districts. Out of the total 195 microscopy positive samples from Khyber district, 164 (84\%) samples were confirmed as positive through nPCR. Moreover, these nPCR confirmed samples comprised of 129/162 cases of $P$. vivax (79.6\%) and 28/33 cases of P. falciparum (85\%). An additional seven patients were infected with mixed infection through PCR detection, which was not evident from microscopy. Thirty-one of the microscopy-positive samples were negative through
PCR. Among 190 malaria positive isolates collected from the Bajaur district, 161 could be confirmed through PCR (84.7\%). The positive detection ratio was 126/158 (79.7\%) in $P$. vivax and $26 / 30$ (86.7\%) for P. falciparum. Molecular testing revealed mixed infection in 9 samples compared

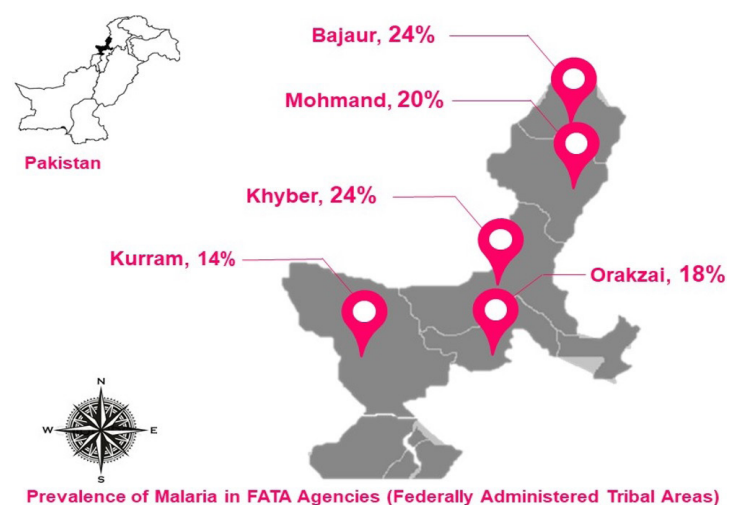

Figure 2. Overall prevalence of malaria infection in different agencies of FATA region.

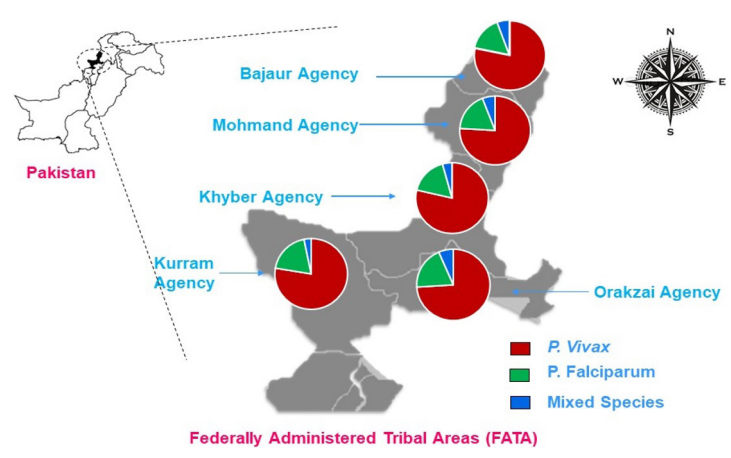

Figure 3. Distribution of Plasmodium species confirmed by PCR in warn-torn FATA region.

Table 1. Breakup of Plasmodium species by Microscopy and PCR.

\begin{tabular}{cccccc}
\hline & P. vivax & P. falciparum & Mixed & Negative & Total \\
\hline Microscopy & $623(82 \%)$ & $132(17 \%)$ & $7(1 \%)$ & 0 & 762 \\
PCR & $523(77 \%)$ & $121(18 \%)$ & $35(5 \%)$ & 83 & 762 \\
\hline
\end{tabular}

Table 2. Gender wise breakup of PCR positive samples for Plasmodium species.

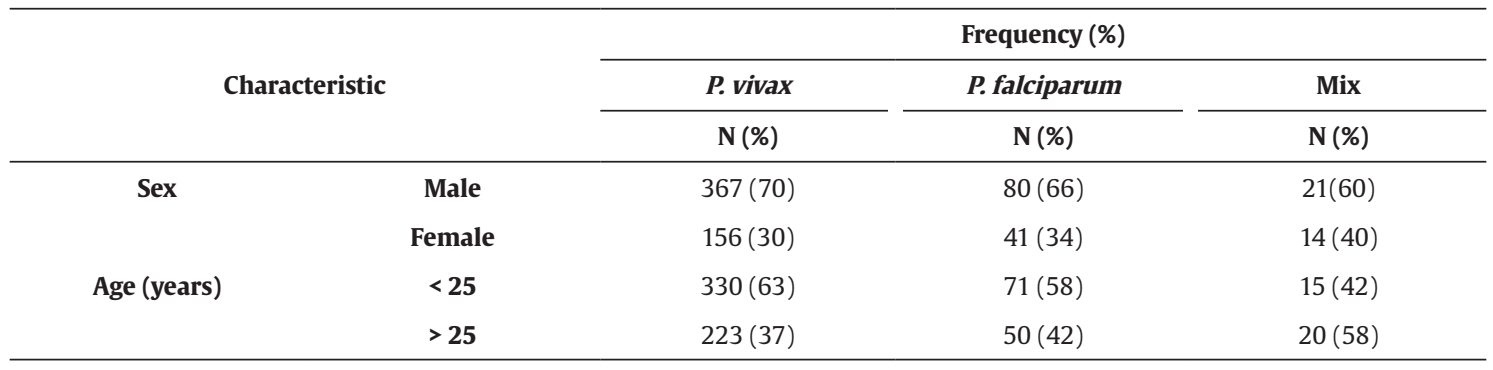


Table 3. Area wise breakup of PCR positive samples for Plasmodium species.

\begin{tabular}{|c|c|c|c|c|c|c|c|c|}
\hline \multirow{3}{*}{ FATA AGENCIES } & \multicolumn{8}{|c|}{ PCR } \\
\hline & \multicolumn{2}{|c|}{ P. vivax } & \multicolumn{2}{|c|}{ P. falciparum } & \multicolumn{2}{|c|}{ Mix } & \multicolumn{2}{|c|}{ Total } \\
\hline & $\mathbf{N}$ & $\%$ & $\mathbf{N}$ & $\%$ & $\mathbf{N}$ & $\%$ & $\mathbf{N}$ & $\%$ \\
\hline Bajaur & 126 & 18.6 & 26 & 3.8 & 9 & 1.3 & 161 & 23.7 \\
\hline Mohmand & 104 & 15.3 & 25 & 3.7 & 8 & 1.2 & 137 & 20.2 \\
\hline Khyber & 129 & 19.0 & 28 & 4.1 & 7 & 1.0 & 164 & 24.2 \\
\hline Orakzai & 91 & 13.4 & 24 & 3.5 & 8 & 1.2 & 123 & 18.1 \\
\hline Kurram Agency & 73 & 10.8 & 18 & 2.7 & 3 & 0.4 & 94 & 13.8 \\
\hline Total & 523 & 77.0 & 121 & 17.8 & 35 & 5.2 & 679 & \\
\hline
\end{tabular}

to 2 cases detected via microscopy. Overall, 29 samples were proven to be negative on PCR.

In the Mohmand district, 137 out of 147 (93.2\%) microscopy-positive samples were also confirmed through PCR for different malarial species. P. vivax was confirmed in 104/122 (85\%) samples, while P. falciparum was found in 25 samples, compared to 22 on microscopy. Eight samples were confirmed for both $P$. vivax and $P$. falciparum PCR. In contrast, seven of the microscopy positive samples tested negative on PCR. Among the samples collected from the Orakzai district, 123 out of 130 (94.6\%) smear-positive malarial samples also proved to be PCR positive. These PCR positive samples included 91/103 (88\%) of $P$. vivax, $24 / 25$ (96\%) samples of $P$. falciparum, and 8 samples positive for both. Seven samples did not amplify on PCR and hence treated as negative. From Kurram district, 94 out of 100 (94\%) slide-positive samples were confirmed through PCR. These included 73/78(93.6\%) P. vivax samples, 18/22 (81.8\%) P. falciparum, 03 mixed infections. Six samples were found negative for PCR. For evaluating disparities between microscopy and PCR, slides were not available for re-examination, but PCR was repeated, and findings were validated in all specimens.

\section{Discussion}

Malaria is one of the top six communicable diseases with deleterious effects on human health and is listed as one of the top medical problems. Especially in highly endemic districts and agencies such as the FATA, malaria has posed a significant public health risk in Pakistan. Efforts of national and local malaria prevention programs, owing to continuing armed wars and the Talibanization of Fata, are appallingly hampered. Seeing this situation, epidemiological analysis is constructive in warped healthcare environments, although this is important for disease prevention and control (Hussain et al., 2016, Karim et al., 2016).

In this study, malaria prevalence was about $21 \%$ that was even higher than previously reported by about $18 \%$ (Pakistan, 2019). Malaria prevalence was highest in males than females, and patients with age less than 20 years of age were more infected. Socio-cultural activity between males and females in this region is more distinct; thereby, external factors such as task sharing, access to infection sources, and mobility might misleadingly create a gender partiality. In addition, this disparity in the spread of malaria across gender may be attributed to stringent limitations on women entering the hospital without accompanying males. Dreadfully, in extreme poverty, families from such remote areas may not afford medical care to a sick woman, which results in the incorrect report (Karim et al., 2016). Similar malaria infection rates have been observed in several studies for both genders in other Pakistani provinces (Karim et al., 2016; Khatoon et al., 2009; Khattak et al., 2013b). The predominance of malaria in males is that they linger outdoors for jobs, contributing to an elevated risk of infected mosquitoes' bites. Contrary, women mostly remain at home; even though they go outside in a burka from head to toe, they will shelter them from a mosquito bite (Hussain et al., 2016). As a result, males are more vulnerable to Anopheles bites, so male malaria patients are lopsided.

In this study, a comparison of PCR and microscopic detection reveals that PCR is more sensitive and specific relative to the microscopic technique. Microscopy revealed only 7 (1\%) isolates with mixed-species infection; however, nPCR declared 35 (5\%) as mixed species infection. In present studies, eight microscopically declared $P$. falciparum and $20 P$. vivax clinical isolates were later exposed as mixed-species infection through PCR. The inefficiency of microscopy and the high efficiency of PCR to differentiate single and mixed species infection has been documented from Iran, India, and Southern Ethiopia (Ebrahimzadeh et al., 2007; Ehtesham et al., 2015; Siwal et al., 2018; Mekonnen et al., 2014). A study conducted in Iran on clinical isolates from Afghanistan, Pakistan, and Iran has reported varying incidences of mixed-species infection $23.5 \%, 22 \%$, and $6.5 \%$, respectively (Zakeri et al., 2010a). This might be due to the predominance of one species over others during the infective condition. Identification of less or occasional prevalent species is a challenging task for expert microscopists in the presence of dominant and common species (Tham et al., 1999; Johnston et al., 2006; Conway, 2007). PCR supremacy over routine microscopy in detecting malaria infection has been reported by many studies (Zakeri et al., 2010b; Rodulfo et al., 2007; Haghdoost et al., 2006; Viana et al., 2021). 
$\mathrm{KP}$ is malaria-endemic, and its endemicity increased due to the influx of 0.7 million internally displaced peoples from malaria-endemic North Waziristan (FATA/Tribal district) to neighboring KP districts. Cross-border migration worsen the malaria epidemiological situation, and a study found a $19 \%$ prevalence, which is even more than the previously reported 17\%. A study in 2016 recorded 86\% of $P$. vivax and $12 \%$ of $P$. falciparum with a mixed-species infection of just $2 \%$ only (Karim et al., 2016). According to the Malaria Control Program report 2019, the distribution of Plasmodium species in the FATA region was $92 \%, 8 \%$, and $1 \%$ P. vivax, $P$. falciparum, and coexistence of both species in one infection, respectively. According to the Malaria Control Program report 2019, the Khyber agency was with the highest malaria burden in terms of prevalence, followed by South Waziristan, Mohmand, and then North Waziristan (Pakistan, 2019).

During this study, malaria incidence was at its peak due to several factors, including low socioeconomic, politically unstable climate, through border migration of Afghani people, and the internal influx of IDPs from FATA war-torn areas to neighboring politically secure agencies. Approximately one million IDPs constitute $73 \%$ of women and children resettled in local communities and camps (Qureshi et al., 2020b; Karim et al., 2016; Pakistan, 2019). Species-specific Plasmodium transmission may vary due to sample collection time at study sites. Blood sampling was carried out during the peak favorable season to seasonal segregation of the species that detected the peaks of $P$. falciparum between August and December and $P$. vivax between April and September. Various studies have already documented this seasonal and malaria occurrence (Mukhtar, 2009; Khatoon et al., 2009; Khattak et al., 2013b).

According to the Malaria Control Program, the regional breakdown indicates that, in 2018, Sindh registered the highest frequency of malaria cases, i.e., 34\%, followed by KP $31 \%$, FATA $18 \%$, Baluchistan $16 \%$, less than one $\%$ in Punjab and Azad Jammu Kashmir both (Pakistan, 2019). Comparatively, in 2013, the malaria reports revealed the highest prevalence from the other provinces in Baluchistan, Sindh, and KP, with 12\%, 11\%, and 10.8\% (Khattak et al., 2013b).

However, considering the successful documentation on malaria prevalence, the study's limited sample size is the main drawback. The primary reason for the limited sample size was the challenges in collecting blood samples due to the involvement of security forces and militants from the Taliban. However, this is the first study documenting malaria prevalence in all agencies in the FATA region. This study's present findings are recommended to carry out malaria eradication and public awareness campaigns in these areas of minimal health facilities to address the increasing prevalence of malaria.

\section{Acknowledgements}

We thank the study participants for their involvement in the study and the anonymous reviewer for comments that substantially improved the manuscript.

\section{References}

BOUMA, M.J., PARVEZ, S., NESBIT, R. and WINKLER, A., 1996. Malaria control using permethrin applied to tents of nomadic Afghan refugees in northern Pakistan. Bulletin of the World Health Organization, vol. 74, no. 4, pp. 413-421. PMid:8823964.

CONWAY, D.J., 2007. Molecular epidemiology of malaria. Clinical Microbiology Reviews, vol. 20, no. 1, pp. 188-204. http://dx.doi. org/10.1128/CMR.00021-06. PMid:17223628.

EBRAHIMZADEH, A., FOULADI, B. and FAZAELI, A., 2007. High rate of detection of mixed infections of Plasmodium vivax and Plasmodium falciparum in South-East of Iran, using nested PCR. Parasitology International, vol. 56, no. 1, pp.61-64. http://dx.doi. org/10.1016/j.parint.2006.12.001. PMid:17257891.

EHTESHAM, R., KESHAVARZ, H., RAEISI, A., HEIDARI, A. and FAZAELI, A., 2015. Detection of mixed-species infections of Plasmodium falciparum and Plasmodium vivax by nested PCR and rapid diagnostic tests in southeastern Iran. The American Journal of Tropical Medicine and Hygiene, vol. 93, no. 1, pp. 181-185. http:// dx.doi.org/10.4269/ajtmh.14-0650. PMid:25962771.

GAYER, M., LEGROS, D., FORMENTY, P. and CONNOLLY, M.A., 2007. Conflict and emerging infectious diseases. Emerging Infectious Diseases, vol. 13, no. 11, pp. 1625-1631. http://dx.doi.org/10.3201/ eid1311.061093. PMid:18217543.

HAGHDOOST, A.-A., MAZHARI, S. and BAHADINI, K., 2006. Comparing the results of light microscopy with the results of PCR method in the diagnosis of Plasmodium vivax. Journal of Vector Borne Diseases, vol. 43, no. 2, pp. 53-57.

HUSSAIN, I., QURESHI, N.A., AFZAL, M., SHAHEEN, N., ALI, A. and ASHRAF, A., 2016. Prevalence and distribution of human Plasmodium infection in Federally Administrative Tribal Areas of Pakistan. Acta Parasitologica, vol. 61, no. 3, pp. 537-543. http:// dx.doi.org/10.1515/ap-2016-0071. PMid:27447217.

JOHNSTON, S.P., PIENIAZEK, N.J., XAYAVONG, M.V., SLEMENDA, S.B., WILKINS, P.P. and DA SILVA, A.J., 2006. PCR as a confirmatory technique for laboratory diagnosis of malaria. Journal of Clinical Microbiology, vol. 44, no. 3, pp. 1087-1089. http:// dx.doi.org/10.1128/JCM.44.3.1087-1089.2006. PMid:16517900.

KARIM, A.M., HUSSAIN, I., MALIK, S.K., LEE, J.H., CHO, I.H., KIM, Y.B. and LEE, S.H., 2016. Epidemiology and clinical burden of malaria in the war-torn area, Orakzai Agency in Pakistan. PLoS Neglected Tropical Diseases, vol. 10, no. 1, pp. e0004399. http:// dx.doi.org/10.1371/journal.pntd.0004399. PMid:26809063.

KHAN, A.Q., PERNAUTE-LAU, L., KHATTAK, A.A., LUIJCX, S., AYDIN-SCHMIDT, B., HUSSAIN, M., KHAN, T.A., MUFTI, F.U. and MORRIS, U., 2020. Surveillance of genetic markers associated with Plasmodium falciparum resistance to artemisinin-based combination therapy in Pakistan, 2018-2019. Malaria Journal, vol. 19, no. 1, pp. 206. http://dx.doi.org/10.1186/s12936-02003276-8. PMid:32513171.

KHATOON, L., MALIK, S.A., BONIZZONI, M., BALIRAINE, F.N. and YAN, G., 2009. Prevalence of antimalarial drug resistance mutations in Plasmodium vivax and $P$. falciparum from a malaria-endemic area of Pakistan. The American Journal of Tropical Medicine and Hygiene, vol. 81, no. 3, pp. 525-528. http://dx.doi.org/10.4269/ ajtmh.2009.81.525. PMid:19706926.

KHATTAK, A.A., VENKATESAN, M., NADEEM, M.F., SATTI, H.S., YAQOOB, A., STRAUSS, K., KHATOON, L., MALIK, S.A. and PLOWE, C.V., 2013a. Prevalence and distribution of human Plasmodium infection in Pakistan. Malaria Journal, vol. 12, no. 1, pp. 297. http://dx.doi.org/10.1186/1475-2875-12-297. PMid:23984968.

KHATTAK, A.A., VENKATESAN, M., NADEEM, M.F., SATTI, H.S., YAQOOB, A., STRAUSS, K., KHATOON, L., MALIK, S.A. and PLOWE, C.V., 2013b. Prevalence and distribution of human Plasmodium 
infection in Pakistan. Malaria Journal, vol. 12, no. 1, pp. 297. http://dx.doi.org/10.1186/1475-2875-12-297. PMid:23984968.

MEKONNEN, S.K., ASEFFA, A., MEDHIN, G., BERHE, N. and VELAVAN, T.P., 2014. Re-evaluation of microscopy confirmed Plasmodium falciparum and Plasmodium vivax malaria by nested PCR detection in southern Ethiopia. Malaria Journal, vol. 13, no. 1, pp. 48. http://dx.doi.org/10.1186/1475-2875-13-48. PMid:24502664

MORSE, S., 2004. Factors and determinants of disease emergence. Revue Scientifique et Technique, vol. 23, no. 2, pp. 443-451. http:// dx.doi.org/10.20506/rst.23.2.1494. PMid:15702712.

MUKHTAR, M., 2009. Assessment of community preferences for use of LLINs in Pakistan. Islamabad: Directorate of Malaria Control, Ministry of Health.

MURTAZA, G., MEMON, I.A. and NOORANI, A.K., 2004. Malaria prevalence in Sindh. Medical Channel, vol. 10, no. 2, pp. 41-42.

NAWAZ, S. and DE BORCHGRAVE, A., 2009. FATA: a most dangerous place. Washington: Center for Strategic and International Studies, vol. 15.

PAKISTAN. Directorate of Malaria Control, 2019. Pakistan malaria annual report 2019. Pakistan.

QURESHI, H., IMRAN KHAN, M., AMBACHEW, H., PAN, H. and YE, D., 2020b. Baseline survey for malaria prevalence in Khyber Pakhtunkhwa Province, Pakistan. Eastern Mediterranean Health Journal, vol. 26, no. 4, pp. 453-460. PMid:32338364.

QURESHI, H., IMRAN KHAN, M., AMBACHEW, H., PAN, H.-F. and YE, D.-Q., 2020a. Baseline survey for malaria prevalence in Khyber Pakhtunkhwa Province, Pakistan. Eastern Mediterranean Health Journal, vol. 26, no. 4, pp. 453-460. PMid:32338364.

RODULFO, H., DE DONATO, M., MORA, R., GONZALEZ, L. and CONTRERAS, C., 2007. Comparison of the diagnosis of malaria by microscopy, immunochromatography and PCR in endemic areas of Venezuela. Brazilian Journal of Medical and Biological Research, vol. 40, no. 4, pp. 535-543. http://dx.doi.org/10.1590/ S0100-879X2007000400012. PMid:17401497.

ROWLAND, M., HEWITT, S., DURRANI, N., BANO, N. and WIRTZ, R., 1997. Transmission and control of vivax malaria in Afghan refugee settlements in Pakistan. Transactions of the Royal Society of Tropical Medicine and Hygiene, vol. 91, no. 3, pp. 252-255. http://dx.doi.org/10.1016/S0035-9203(97)90065-1. PMid:9231188.

SANTOS, J.M.M., MAIA, J.D.F. and TADEI, W.P., 2004. Differentiation and genetic variability in natural populations of Anopheles (N.) triannulatus (Neiva\& Pinto, 1922) of Brazilian Amazonia. Brazilian Journal of Biology $=$ Revista Brasileira de Biologia, vol. 64, no. 2, pp. 327-336. http://dx.doi.org/10.1590/S151969842004000200019 . PMid:15462307.

SHEIKH, A.S., SHEIKH, A.A., SHEIKH, N.S. and PARACHA, S.M., 2005. Endemicity of malaria in Quetta. Pakistan Journal of Medical Research, vol. 44, no. 1, pp. 41-50.
SINGH, B., SNOUNOU, G., ABDULLAH, M.S., RAHMAN, H.A., BOBOGARE, A. and COX-SINGH, J., 1999. A genus- and speciesspecific nested polymerase chain reaction malaria detection assay for epidemiologic studies. The American Journal of Tropical Medicine and Hygiene, vol. 60, no. 4, pp. 687-692. http://dx.doi. org/10.4269/ajtmh.1999.60.687. PMid:10348249.

SIWAL, N., SINGH, U.S., DASH, M., KAR, S., RANI, S., RAWAL, C., SINGH, R., ANVIKAR, A.R., PANDE, V. and DAS, A., 2018. Malaria diagnosis by PCR revealed differential distribution of mono and mixed species infections by Plasmodium falciparum and P. vivax in India. PLoS One, vol. 13, no. 3, pp. e0193046. http:// dx.doi.org/10.1371/journal.pone.0193046. PMid:29565981.

SNOUNOU, G., VIRIYAKOSOL, S., JARRA, W., THAITHONG, S. and BROWN, K.N., 1993. Identification of the four human malaria parasite species in field samples by the polymerase chain reaction and detection of a high prevalence of mixed infections. Molecular and Biochemical Parasitology, vol. 58, no. 2, pp. 283-292. http://dx.doi.org/10.1016/0166-6851(93)90050-8. PMid:8479452.

SOARES-PINHEIRO, V.C., DASSO-PINHEIRO, W., TRINDADE-BEZERRA, J. and TADEI, W.P., 2017. Eggs viability of Aedes aegypti Linnaeus (Diptera, Culicidae) under different environmental and storage conditions in Manaus, Amazonas, Brazil. Brazilian Journal of Biology = Revista Brasileira de Biologia, vol. 77, no. 2, pp. 396-401. http://dx.doi.org/10.1590/1519-6984.19815. PMid:27533732.

THAM, J.M., LEE, S.H., TAN, T.M., TING, R.C. and KARA, U.A., 1999. Detection and species determination of malaria parasites by PCR: comparison with microscopy and with ParaSight-F and ICT malaria Pf tests in a clinical environment. Journal of Clinical Microbiology, vol. 37, no. 5, pp. 1269-1273. http:// dx.doi.org/10.1128/JCM.37.5.1269-1273.1999. PMid:10203469.

VIANA, J., SOARES-DA-SILVA, J., VIEIRA-NETA, M., TADEI, W., OLIVEIRA, C., ABDALLA, F., PEIXOTO, C. and PINHEIRO, V., 2021. Isolates of Bacillus thuringiensis from Maranhão biomes with potential insecticidal action against Aedes aegypti larvae (Diptera, Culicidae). Brazilian Journal of Biology $=$ Revista Brasileira de Biologia, vol. 81, no. 1, pp. 114-124. http://dx.doi. org/10.1590/1519-6984.223389.

WORLD HEALTH ORGANIZATION - WHO, 2019. World malaria report 2019. Geneva: WHO.

ZAKERI, S., AFSHARPAD, M., GHASEMI, F., RAEISI, A., SAFI, N., BUTT, W., ATTA, H. and DJADID, N.D., 2010a. Molecular surveillance of Plasmodium vivax dhfr and dhps mutations in isolates from Afghanistan. Malaria Journal, vol. 9, no. 1, pp. 75. http://dx.doi. org/10.1186/1475-2875-9-75. PMid:20226087.

ZAKERI, S., KAKAR, Q., GHASEMI, F., RAEISI, A., BUTT, W., SAFI, N., AFSHARPAD, M., MEMON, M.S., GHOLIZADEH, S., SALEHI, M., ATTA, H., ZAMANI, G. and DJADID, N.D., 2010b. Detection of mixed Plasmodium falciparum \& P. vivax infections by nested-PCR in Pakistan, Iran \& Afghanistan. The Indian Journal of Medical Research, vol. 132, pp. 31-35. PMid:20693586. 